\section{Introduction: The African Scene}

Relatively little research has been done on African plantations, and some of the findings from Asian studies do not apply to Africa. In Kenya where the poorest are the rural landless, and the plantation workforce is indigenous, plantation workers seem to be considerably less disadvantaged in terms of poverty, income and food security indicators than the rural landless. Plantations provide one of the few sources of employment for this group; but as population pressure on land rises, and plantations no longer need to attract labour, the relatively favourable conditions of Kenyan tea plantation workers may deteriorate. Large Kenyan tea estates are atypical and conditions on them may be exceptional; but the case study is all the more interesting for this, as it raises questions not normally posed in the plantation context.

In the first part of this article the indirect links between people in plantations and in the rural economy are discussed. In the second part, available data on basic needs provision in plantations and provision in the areas from which plantation workers originate are compared. In the third, arguments for and against the employment of the rural landless in plantations are explored. In the final section, food security among plantation workers and the rural poorest is discussed.

\section{Plantations and their Immediate Rural Economy}

Plantations are rarely discussed in the context of their immediate rural economy. This is because they tend to be considered either in terms of their internal structure (e.g. labour/management relations, levels of provision of certain services); or in terms of the extent to which they are influenced by national or global macro-level factors (e.g. government legislation, foreign exchange earnings, world commodity price trends, transnational corporations).

This artificial division was originally justified by Boeke's (1946) dual economy thesis, which argued that the contrast between plantation agriculture and peasant farming is sharp enough to allow these two sectors to be conceptualised as separate and unrelated. Although this thesis has now been largely refuted, the study of plantation/rural economy linkages has focused on either the direct links between smallholders and plantations (e.g. seasonal employment) or those between smallholders and transnational agribusinesses via contract farming (e.g. Kirk, in this Bulletin). This article is concerned with indirect links which, while less obvious than formal relations between plantations and smallholders (or rural wage labourers), nevertheless have direct implications for the development of basic needs in plantations and, indeed, for the development of plantations themselves.

Unlike many Asian plantation economies, where the comparison between plantation labour and the urban workforce and/or informal sector is appropriate, in an overwhelmingly rural economy such as Kenya's, this comparison would be false. Landless Kenyans have few opportunities for non-rural employment, either in urban or informal sectors. The plantation workforce comes from landless or near-landless rural producers, and plantations often offer the only available type of regular employment in the area. Consequently, it is more appropriate in the Kenyan context to compare the plantation workforce with the immediate rural economy - and the poor within it - than with a distant and small urban workforce.

The most fundamental change occurring in the relation between plantations in Kenya and their immediate rural economy is the increasingly synergistic relationship between a plantation's demand for labour (due to its labour-intensive methods of production) and pressure on land in the rural economy, leading to rural landlessness and hence, unemployment, poverty and hunger. The historical problem of labour shortage on plantations, which resulted in slavery, indenture and migrant workforces, is no longer necessarily characteristic of plantations. This is certainly true on Kenyan tea plantations.

Kenya represents a country which: (a) has a plantation sector coexisting with smallholder agriculture and which makes a major contribution to foreign exchange earnings; (b) has an extremely high rate of population growth (over four per cent a year); (c) is fast approaching a land frontier; and (d) shows increasing and alarming levels of rural poverty, un- or underemployment and undernutrition [World Bank 1982]. Consequently, labour in the Kenyan rural economy is in surplus and will continue to increase 
with population growth, in the absence of alternative sources of non-agricultural employment.

This situation has direct implications for the development of basic needs on plantations. We start from the premise that any such improvements are more likely to occur when labour is in short supply (and therefore needs to be attracted) than when it is in surplus. A labour shortage is therefore a necessary, but not sufficient, precondition to bring about improved provision of basic needs on plantations. Obviously, if slavery or indenture is the basis of labour recruitment, labour does not respond to market incentives. But increasingly, especially in countries where the plantation workforce is indigenous, plantation labour - although not entirely 'free' - is subject to market forces, however imperfect. But if the labour market around plantations is always in surplus, the impetus for the plantation to attract labour via payment of higher wages or provision of health care or schooling, declines. Equally, as the local rural economy becomes increasingly stressed and poverty and landlessness rise, access to basic needs by the rural poorest outside the plantation will also decline or stagnate.

So, the rural poorest may well be caught between pincers of declining basic needs off the plantation and, on the other hand, reduced incentives on the plantation to improve basic needs and wage levels, since labour is in surplus.

There is one important proviso to this line of argument. If labour is recruited locally, the plantation workforce is no longer culturally, geographically and politically isolated as is the case for classically 'unfree' plantation labour imported from elsewhere (e.g. Indian Tamils in Sri Lanka). It is still politically weak, as are all rural poor, but it is not necessarily entirely politically impotent. Effective government legislation may, therefore, intervene to ensure higher minimum levels of basic needs for plantation workers than is the case for non-indigenous plantation workforces.

\section{Tea Plantations, Rural Poverty and Access to Basic Needs}

The classical idea of the plantation as a closed economic and social community, in which labour is 'unfree' and which has few links with the surrounding rural economy, no longer applies to Kenyan tea plantations. As population pressure on land has risen, the workforce has become almost entirely Kenyan, replacing Tanzanian migrant labour. Eighty per cent of the workforce is male, many leaving women and children behind on a smallholding which is no longer sufficient to provide an adequate family income. A significant and rising (but unquantified) proportion of workers are entirely landless, in which case families either join the male workforce on the plantation or remain with relatives on a smallholding. Since health care and schooling on large tea estates in Kenya is free, it is increasingly common for poorer households to send at least one family member with the male worker to take advantage of these, and for some women to seek employment on the plantation.

No systematic data collection comparing the provision of basic needs on plantations with that in the areas where workers come from (principally Western Province) has been carried out. But a few examples illustrate that the rural poorest may be better served within the plantation environment than if they remain as landless (or near landless) labourers in some of Kenya's poorest districts (e.g. South Nyanza, Siaya). The African Highlands Produce Company (AHPC), a subsidiary of James Finlay plc (with over 7000 hectares of tea estates), has 19 dispensaries on estates with about 45,000 workers [Davies 1986]. In contrast, the entire district of South Nyanza has 41 dispensaries (32 of which are state run) and 24 health centres (13 of which are state run), where the number of children under five alone exceeded 190,000 in 1980. There is only one government hospital in South Nyanza (and two mission hospitals) whereas all AHPC tea estates have their own hospital or ambulance services to a hospital run by a neighbouring estate. In Kericho district, where most of the AHPC tea estates are, there are 115 health centres and dispensaries, of which 55 are government run (the under-five population is 160,000) [Davies and Lipton, 1986, based on Ministry of Health data]. Visits to plantation dispensaries and health centres and their state-run counterparts revealed stark contrasts, in favour of the former, in terms of levels of hygiene, trained staff, equipment and medical supplies.

These observations are clearly qualitative. However, they do serve to illustrate that: (a) if the plantation labour force comprises formerly landless or nearlandless unemployed workers; and crucially, (b) if the plantation needs to attract labour, the access of such workers to basic needs services may actually improve when they are employed on a plantation, given the very low level of provision in the local rural economy.

It is important to note, however, that on the smaller tea plantations (50-100 hectares), owned by individuals rather than large agribusiness firms, provision for basic needs is far poorer than on the big estates and in some cases, is virtually non-existent. Such farms account for about a third of total tea estates (by hectarage) in Kenya, but no data are available on the level of basic needs provision.

A second important qualification is that the labour requirements for tea estates in Kenya are not seasonal. Tea is plucked throughout the year, owing to the equatorial latitude of the estates, with few fluctuations in labour needs. Large tea estates were the first plantations to put workers on permanent terms, after 
three months service [Leitner 1976]. Crops that have seasonal labour requirements (e.g. sisal, coffee) and smaller plantations that cannot afford the risk of a large permanent (and possibly idle) workforce, employ labour only as it is required.

\section{Plantation Labour, Rural Landlessness and Employment}

Most descriptions of plantation labour focus on workers already tied to the plantation system. For example, the idea of 'unfree' labour is primarily concerned with the lack of choices to leave the plantation rather than whether to seek employment there in the first place [de Silva 1985]. Although this may be a valid description of some plantation workforces today, it can cloud the issue for those who may be 'choosing' between rural landlessness and regular rural wage labour.

This is not to argue either that the workers' decision is desirable or that the individuals concerned are "spoilt for choice'. However, if plantations are analysed as providing a source of employment in local rural economies facing high population growth rates and a land crunch, any discussion of basic needs must include a different set of issues from those concerned simply with the development of basic needs within plantations. The double threat to basic needs levels when local labour is in surplus - declining levels off the plantation for the rural poorest, and no need to attract labour on to the plantation, either by higher wages or better services - could well continue to disadvantage plantation workers, potential and actual.

A second argument with respect to plantation labour and rural landlessness concerns the high labour intensity of plantation production, sometimes regarded as indicating a lower level of socioeconomic development. But the high labour-intensity means that there is some potential for creating jobs for the rural landless. Again, Kenyan tea plantations are a somewhat special case in this respect. Unlike elsewhere, production and employment on Kenyan tea estates have risen together. This is due in particular to extremely high yields $(2500 \mathrm{~kg} / \mathrm{ha}$ of made tea compared with an average of about $850 \mathrm{~kg} / \mathrm{ha}$ in Sri Lanka), with high labour-intensity maintained by hand plucking.

It is ironic that whilst rural development 'experts' are at last decrying the capital intensity of the large-scale farming experiments of the 1960s and 1970s, rightly arguing that they are inappropriate in societies where lack of purchasing power due to un- or underemployment is the major cause of poverty and hunger, some plantation theorists persist in decrying the labour intensity of plantations. What is wrong with plantations is not that they are labour intensive, but rather that plantation labour is paid insufficiently to meet basic needs and that living and working conditions are very poor.

Counterarguments to the employment-creating potential of plantations often revolve around the issue of land reform in Kenya. It is argued that in countries where there is rural landlessness caused by land shortage, solutions lie in the redistribution of land in favour of small (and poor) farmers [see, e.g., Hunt 1984]. This argument is reinforced by evidence which shows that because small farmers 'saturate' the land with labour, yields per hectare tend to be higher on smallholdings than on large farms [see World Bank 1982, for Kenyan examples].

But there are two very important qualifications to this argument with respect to plantations. First, the evidence collected is based on mixed farming rather than plantation production (and yields for smallholder tea in Kenya are significantly lower than for plantation tea - $830 \mathrm{~kg} / \mathrm{ha}$ compared with $2500 \mathrm{~kg} / \mathrm{ha}$ ). Second, national dependence on foreign exchange earnings from plantation produce mèans that breaking up plantations is both politically and economically unattractive. In Sri Lanka, for example, the nationalisation of the tea estates included provision for some redistribution of land to smallholders, but the majority of land remained in large units [Kurian 1982]. Plantation production of cash crops continues to be justified by the asertion that smallholders cannot produce the same economies of scale as plantations and consequently cannot compete on world markets. Again, the Kenyan tea sector is a special case, because smallholder tea production has been very successfully organised by the Kenya Tea Development Authority (KTDA). But smallholder cash crop production may not be the best option for the rural poorest, dependent on income not land for their basic needs.

Data show the income effects of Kenyan smallholder tea production to be positive for the smallholders. Buch Hansen [1980] estimated a net annual income for an average grower (with 0.4 ha of mature tea and 0.4 ha of land sown to food crops) to be Ksh 3850 in $1980 / 81$. This had risen to Ksh 5,817 in $1982 / 83$ and Ksh 10,293 in 1983/84 (net of tea cess, but gross of fertiliser, labour and other costs) [Davies 1986, based on KTDA data). 1983/84 was an exceptional year, with high tea prices paid on world markets, but smallholder tea growers enjoy an above average standard of living even in a normal year. In comparison, average agricultural sector employee wages were Ksh 4290 in 1980 (i.e. 10 per cent more than a tea grower's); but the average wage assumes constant employment and unlike the tea grower, the employee may have no land on which to grow food.

Discussions of the benefits of smallholder versus plantation cash crop production rarely consider the 
effects on the rural poorest (who are seeking rural employment). There are, for example, no estimates of the relative labour intensity of Kenyan smallholder and estate tea production. Equally, no data exist to show relative wage rates between estate labour and casual labour employed by smallholders for tea plucking. Leitner [1976] argues that casual rural wages paid by smallholders are amongst the lowest in Kenya, not least because the smallholders themselves face a cash flow constraint in hiring labour [see Davies 1986].

Data do exist for tea plantation workers' wages and provide interesting comparisons with other wage rates. Tea plantation wages in Kenya are calculated on the basis of a fixed daily payment of Ksh 18.50 for the first $32 \mathrm{~kg}$ of green leaf plucked, and a supplement of Ksh $0.58 / \mathrm{kg}$ for additional tea plucked (1985 rates). A good worker can pluck up to $60 \mathrm{~kg}$ a day, but $30-40 \mathrm{~kg}$ is more usual. Estate management claims that maximum household earnings could be as much as Ksh 2,500 a month, but a more realistic estimate (assuming the target of $32 \mathrm{~kg}$ is reached over 26 days) is only Ksh 481 a month. Although very low, this figure needs to be set in context: the minimum civil service wage in Nairobi was raised to Ksh 550 at the end of 1985, where living costs are higher and housing, health care and schooling - all provided free on large Kenyan tea estates - must be paid for. Moreover, a proportion of Kenyan tea workers have at least some of their family still engaged in subsistence food production off the plantation. Unfortunately, no data exist to show the flow of resources between the plantation worker and the family smallholding.

As explained above, the large Kenyan tea estates may give an unduly favourable impression with respect to wage rates and provision of basic needs. They are a somewhat special case in that labour requirements are not seasonal, so problems of irregular employment and casual labour arise infrequently. Also, because available information concerns the largest estates, owned by foreign agribusiness (notably Brooke Bond Leibig and James Finlay), it is not applicable to all tea estates. Smaller, individually-owned estates are both less able to afford health services, etc.; and being locally-owned, probably less vulnerable than are foreign companies to government criticism of poor facilities.

Nevertheless, these qualifications do not detract from the fact that in a local rural economy, which is short of land and employment opportunities, the rural landless may have a greater chance of meeting their basic needs on, rather than off, the plantation. The key issue, then, is whether this situation of surplus labour leads to declining levels of provision for basic needs on plantations, which are safe in the knowledge that labour is queueing up at the gate.

A further question in the context of rural landlessness is whether plantations survive because labour has no employment opportunities elsewhere or, alternatively, whether plantations ensure that these opportunities are not created. The land reform option, though not strictly closed, is certainly complex and probably not on the immediate agenda for the Kenyan Government. At the moment, plantations do at least provide employment for the rural landless, offering both a higher rate of pay and better provision of basic needs than other rural employers. If the possibility of declining incentives on plantations to maintain or improve basic needs and wage rates is to be avoided, more data and research comparing poverty and income levels in and around plantations is needed.

\section{Food Security and Undernutrition on and off Plantations}

Plantation workers are generally, and correctly, classified as being amongst the most disadvantaged members of poor societies. Wage levels and health and nutritional status compare unfavourably with other groups [e.g. Laing 1986]. However, the lack of data in many countries on the rural poorest (or, perhaps, too high cut-off points to distinguish landless from near landless; moderately malnourished from severely malnourished, or seasonally hungry from always hungry - [see Davies and Lipton, 1986 for examples from Kenya and Lipton 1983), may mean that plantation workers are not being directly compared with the poorest non-plantation rural population. In parts of Asia, this may be a justifiable omission, given a relatively large urban and informal sector workforce. But in most African countries, a comparison between plantation labour and the rural landless is meaningful since urban/rural linkages are so much less developed, especially for the poorest. Indeed, failure to compare the status of workers on plantations (whether in terms of income or basic needs' indicators) with that of the poorest (landless) members of the local rural economy may result in artificial comparisons between levels of poverty in plantations and those elsewhere in the economy.

Food security, whether individual or household, is an important element in the improvement of basic needs on plantations, and also serves as a point of comparison between plantation workers and the rural poorest. Both groups buy (or exchange labour for) a considerable proportion of food consumed. As such, both are more vulnerable to rising food prices and seasonal fluctuations in food availability, than are subsistence farmers meeting most or all of their food needs by their own production.

Food on large Kenyan tea plantations is supplied partly through individual plots of land allocated to workers on the larger estates; partly through estate shops; partly through food rations; and, in drought 
years partly via free distribution by the company. But since women are responsible for food crop production, male workers unaccompanied by their families tend not to take up the option of growing their own food, and instead purchase, food in estate stores. This is probably due to time constraints.

No data exist on the prevalence of undernutrition on Kenyan tea estates, but data are available for neighbouring areas. In 1982 , the stunting $(<90$ per cent height-for-age) prevalence in the main tea plantation district, Kericho, was 18.1 per cent of children under five. This compares with a national average of 24.0 per cent. However, in the poorer districts to the west of Kericho, where many tea plantation workers come from, the situation is worse. In South Nyanza, the stunting prevalence was 25.3 per cent; and in Siaya it was 36.6 per cent. Siaya has the third highest prevalence of stunting in Kenya and South Nyanza ranks eighth [Central Bureau of Statistics 1983].

As would be expected, the areas currently supplying plantation labour show a higher incidence of chronic child undernutrition than the national average. What is not known, of course, is: (a) how this compares with rates on plantations; or (b) whether the nutritional status, and hence household food security, of the rural poorest and their families improve or decline when either one family member or the entire family seeks employment on plantations. But whereas Laing [1986] has found the nutritional status of plantation workers to be lowest of all agricultural groups in Zimbabwe, this might not be the case in Kenya, which has certain extremely stressed districts with high levels of rural unand underemployment, showing very high rates of undernutrition.

From the point of view of overall rural development in general, plantations' heaviest threat to the development of basic needs and, by implication, to food security, is their consumption of scarce agricultural resources (land, inputs, capital) for the production of non-basic crops. The impact of this is exacerbated by the lack of links between plantations and the rest of the agricultural sector in respect, for example, of agricultural research. More importantly, tax revenue from plantation crops is typically not reinvested in the agricultural sector in many developing countries. Arguments concerning the penalising of agriculture in the economy as a whole, and the preferential treatment given to large-scale cash crop production within the agricultural sector are complex; but three issues are significant here.

First, it is extremely unlikely that most governments dependent on plantation crop exports for most of their foreign exchange earnings will either want, or in the climate of structural adjustment be able, in the medium term, to divert the distribution of land and other inputs away from plantations, in favour of food production and small producers.

Second, even if 'breaking up' plantations were politically and/or economically feasible, it may not necessarily be desirable in efficiency terms, although, of course, equity arguments raise different issues. Briefly, food crop prices are forecast to decline at a faster rate than those of most plantation crops in the medium term, so importing food may be a cheaper option for poor countries than losing precious foreign exchange earnings by switching to food production on plantation land. Moreover, the opportunity costs of plantation land vary tremendously: in Kenya they are high; but in Sri Lanka for example, the level of soil depletion on tea estates suggests that the land would be unsuitable for any other cultivation. Further, if export earnings are not derived from plantation crops, the potential for competitve market expansion in other sectors may be extremely limited.

Third, and most important of all, arguments directed against cash crops per se as being bad for food security, fail to consider that the most common cause of household food insecurity is poverty, i.e. lack of purchasing power. Cash crop production, by creating rural employment and raising smallholders' incomes could improve household food security more than directly increasing food production. However, most successful smallholder cash crop production schemes (of which the Kenya Tea Development Authority is a prime example) so far have concentrated their efforts on relatively prosperous smallholders, with the result that the rural poorest have not benefited.

\section{Conclusions}

The case of Kenyan tea plantations presented here is undoubtedly a special one. Yet it raises questions relevant to plantations generally and the development of basic needs, which are not normally considered. In particular, the move away from non-indigenous migrant labour towards a local labour market in surplus, has direct and contradictory implications for poor people's access to basic needs. For the rural landless, plantations provide one of the few available sources of employment. As such, they represent a means of improving access to basic needs, especially since the immediate rural economy and services within it are stretched. But, on the other hand, as labour supply is secured, the incentive to raise wages, provide services and improve living conditions may decline.

Before any case can be made for the possible positive effects of plantation employment on the rural landless, its effect on their access to basic needs and their household food security, more information is needed. Few detailed studies have been undertaken on levels of basic needs before and after work on a plantation.

A major policy issue which needs to be addressed on the basis of such information is whether the 
development of basic needs provision on plantations can be sustained when the 'disincentive' of rural landlessness and poverty is fully felt. If, by virtue of simply offering employment, even at a very low wage, plantations improve the status of the rural poorest, will the incentive to attract labour with reasonable wages, health services, schooling and housing remain? Or will the 'special case' of Kenyan tea plantations begin to follow a more classical plantation model?

$£ 1=$ ksh 24 (1987).

\section{References}

Boeke, J. H., 1946, The Evolution of the Netherlands Indies Economy, Amsterdam

Buch Hausen, M., 1980, Agro-Industrial Production and Socio-Economic Development: A Case Study of KTDA Smallholder Tea Production in Buret, Western Kenya, Working Paper No. 11, Institute of Geography, SocioEconomic Analysis and Computer Science, Roskilde University Centre, Roskilde

Central Bureau of Statistics, 1983, Third Child Nutrition Survey, 1982, Government of Kenya Printer, Nairobi

Davies, S., 1986, The Kenyan Tea Sector: Domestic and International Bases for Competitiveness, Centre for European Policy Studies/EEC Commodities Project, IDS, Sussex, February
Davies, S. and M. Lipton, 1986, How to Improve the Nutritional Impact of Kenya's National Food Strategy, report to the Government of Kenya and the EEC, Brussels, IDS, Sussex, April (confidential)

Hunt, D., 1984, The Impending Crisis in Kenya and the Case for Land Reform, Gower, Aldershot

Kurian, R., 1982, 'Women Workers in the Sri Lankan Plantation Sector', Women, Work and Development, No. 5, ILO, Geneva

Laing, R., 1986, 'Health and Health Services for Plantation Workers', Evaluation and Planning Centre for Health Care Discussion Paper No. 10, London School of Hygiene and Tropical Medicine, London

Leitner, K., 1976, 'The Situation of Agricultural Workers in Kenya', Review of African Political Economy, No. 6

Lipton, M., 1983, Poverty, Undernutrition and Hunger, World Bank Staff Working Paper No. 597, Washington DC

de Silva, S. B., 1985, 'Plantations and Underdevelopment', in C. Abeysekera (ed.), Capital and Peasant Production, Social Science Association of Sri Lanka, Colombo

World Bank, 1982, Growth and Structural Change in Kenya: A Basic Economic Report. Annex II: Issues in Kenyan Agricultural Development, East Africa Regional Office, Washington DC, August 